\title{
PENGELOLAAN PEMBELAJARAN TEMATIK DI SEKOLAH DASAR NEGERI KECAMATAN BULA KABUPATEN SERAM BAGIAN TIMUR-MALUKU
}

\author{
Nurhayati Suwakul, Suwarjo \\ SMP Negeri 1 Bula Kabupaten Seram Bagian Timur-Maluku, Universitas Negeri Yogyakarta \\ ummusulaim86@yahoo.co.id, suwarjo@uny.ac.id
}

\begin{abstract}
Abstrak
Penelitian ini bertujuan untuk mengetahui bagaimana pengelolaan pembelajaran tematik pada sekolah dasar negeri di Kabupaten Seram Bagian Timur yaitu SDN 1, 2 dan 3 Bula khususnya pada kelas III. Pendekatan penelitian yang digunakan dalam penelitian ini adalah kualitatif yang mengungkapkan fenomena yang terjadi secara apa adanya dan berusaha memaparkan data terkait bagaimana pemahaman pengelola sekolah terhadap penerapan pembelajaran tematik. Adapun hasil dari penelitian ini meliputi perencanaan, setiap guru kelas sudah memiliki perangkat pembelajaran berupa silabus dan RPP tematik. Pelaksanaan, secara perencanaan guru sudah memiliki perangkat pembelajaran tematik, tetapi pada aspek pelaksanaan tidak secara tematik/per mata pelajaran. Penilaian, proses penilaian meliputi ulangan harian (UH) $1 \mathrm{~s} / \mathrm{d} 3$ disusul dengan ulangan tengah semester (UTS) dan ulangan akhir semester (UAS). Dalam pengelolaan pembelajaran tematik ini juga dipengaruhi oleh beberapa faktor, diantaranya guru pada setiap sekolah belum dibekali pelatihan terkait pengelolaan pembelajaran tematik, minim sarana pembelajaran dan jumlah siswa pada setiap kelas diatas 30 orang siswa sehinggan guru sulit dalam melakukan pengelolaan kelas.
\end{abstract}

Kata kunci: Pengelolaan pembelajaran tematik

\section{THEMATIC LEARNING MANAGEMENT IN STATE PRIMARY SCHOOL DISTRICT BULA SERAM EAST-MALUKU}

\begin{abstract}
This study aims to investigate the application of the thematic learning in terms of the planning, implementation, and evaluation aspects and the constraints in the application process in SD Negeri 1 ,2, and 3 Bula especially for grade III. This was a study revealing what happened by using the qualitative approach. The research subjects were teachers of Grade III and head master in each public elementary school in Bula. The results of the study are as follows. 1) The planning of the thematic learning, administratively written, is in the form of learning kits (a syllabus and lesson plans. 2) In terms of the implementation aspect, the thematic learning is not in accordance with the planning made. 3) The evaluation, processing of evaluation includes the evaluation instruments are the form of formative tests 1 to 3, the mid-semester test, the end-semester test, and assignments/exercises done at school or at home. In management of thematic learning effected by some factors, they are teachers teaching in the thematic class have not attended a training/workshop on a thematic learning model, The learning infrastructure facilities do not fully support the effectiveness of the thematic learning process, and the number of students in each standard school is more than 30 so that classroom management is difficult.
\end{abstract}

Keywords: management of thematic learning 


\section{Pendahuluan}

Pemerintah daerah kabupaten Seram Bagian Timur (Dinas Pendidikan) melaksanakan salah satu program peningkatan mutu terkait dengan sarana pembelajaran. Hal ini dapat ditunjukkan dalam situs resmi pemerintah daerah yang menyatakan bahwa Dinas Pendidikan memfokuskan pada program peningkatan guru bermutu dan pemantapan penerapan Kurikulum Tingkat Satuan Pendidikan termasuk memberikan pelatihan/workshop tentang penerapan KTSP dan mengoptimalkan KKG untuk sekolah dasar dan MGMP untuk SMP/SMA. (http//: www. serambagiantimurkab.go.id diambil pada tanggal 1 Januari 2013).

Program-program ini menjadi sebuah bekal dalam proses peningkatan mutu guru dalam menerapkan kurikulum yang menjadi dasar dalam proses pembelajaran termasuk SD Negeri 1, 2 dan 3 Bula. SD Negeri 1, 2, dan 3 Bula merupakan sekolahsekolah yang berada di pusat ibukota kabupaten, dimana sekolah ini seharusnya menjadi icon dalam menerapkan program pendidikan daerah termasuk penerapan kurikulum tingkat satuan pendidikan (KTSP) yang mencakup pengelolaan pembelajaran tematik bagi kelas rendah. Akan tetapi pelaksanaan ini berbeda dengan pernyataan pemerintah yang memfokuskan peningkatan mutu guru dalam menerapkan kurikulum yang disertai dengan pelatihan/pemantapan penerapan KTSP.

Kondisi yang terjadi pada masingmasing sekolah bahwa guru-guru yang ditempatkan pada kelas rendah yang menerapkan pembelajaran belum dibekali dengan konsep tematik yang ideal. Sehingga pengetahuan tentang pengelolaan pembelajaran tematik ini hanya bersifat nama bukan action yang diterapkan oleh guru-guru tersebut. Padahal pemerintah sudah menyatakan bahwa memfokuskan pada program peningkatan mutu guru dalam menerapkan kebijakan pemerintah terkait Peraturan Menteri Pendidikan No 22 tahun 2006.

Berdasarkan atas pernyataan Dinas Pendidikan juga dalam situs resmi peme- rintah daerah yang menyatakan bahwa "menyangkut sarana pembelajaran, Dinas Pendidikan secara bertahap mengupayakan melengkapi seluruh sekolah dengan laboraturium memadai, perpustakaan yang representatif dan komputer untuk guru dan praktik murid". (http//: www. serambagiantimurkab.go.id diambil pada tanggal 1 Januari 2013). Hal ini tentu menjadi faktor pendukung dalam proses pelaksanaan pembelajaran, akan tetapi kenyataannya SD Negeri 1, 2, dan 3 Bula belum memiliki laboraturium. Padahal dalam pengelolaan pembelajaran tematik idealnya didukung dengan laboraturium yang memadai yang tentunya berbagai sumber belajar yang dibutuhkan ada dalam laboraturium tersebut. Hal ini selaras dengan pernyataan Suryosubroto (2009, p.132) bahwa pembelajaran tematik ini akan dapat diterapkan dan dilaksanakan dengan baik perlu didukung dengan laboraturium yang memadai tentunya berisi berbagai sumber belajar yang dibutuhkan bagi pembelajaran di sekolah.

Standar sarana menjadi bagian penting dalam pengelolaan pembelajaran. Sarana yang memenuhi standar dapa memberikan efek positif dalam peningkatan kualitas pendidikan. Berikut pernyataan Mulyasa terkait Mulyasa (2010, p.37), standar sarana dan prasana adalah standar nasional pendidikan yang berkaitan dengan kriteria minimal tentang ruang belajar, tempat berolahraga, tempat beribadah, perpustakaan, laboraturium, bengkel kerja, tempat bermain, tempat berkreasi serta sumber belajar lain yang diperlukan untuk menunjang proses pembelajaran termasuk penggunaan teknologi, informasi dan teknologi.

Sarana belajar menjadi penunjang dalam proses pembelajaran dimana juga membutuhkan ruang sumber belajar. Ruang sumber belajar merupakan jantung sekolah seperti halnya perpustakaan. Terdapat keuntungan bagi sekolah yang memiliki kelengkapan sarana dan prasarana. Pertama, kelengkapan sarana dan prasarana dapat menumbuhkan gairah dan motivasi mengajar guru. Kedua, keleng- 
kapan sarana dan prasarana dapat memberikan berbagai pilihan kepada siswa untuk belajar.

Dalam pengelolaan pembelajaran tematik juga menjadikan siswa belajar secara langsung terkait dengan objek materi yang dipelajari. Proses pembelajaran ini tentu didukung dengan berbagai sumber belajar yang memungkinkan siswa mengalami proses pembelajaran secara kontekstual bukan abstrak. Karena untuk membentuk pemahaman siswa yang utuh seharusnya siswa secara aktif diarahkan pada proses tersebut sehingga dapat membentuk pola pemahaman yang kreatif dan inovatif. Hal ini juga dipengaruhi oleh pengetahuan guru dalam mengelola pembelajaran tematik sesuai dengan tuntutan KTSP. Pernyataan ini sesuai dengan apa yang dituturkan Anggani Sudono (2010, p.33) sumber belajar adalah bahan termasuk juga alat permainan untuk memberikan informasi maupun berbagai keterampilan kepada siswa maupun guru antara lain buku referensi, buku cerita, gambar-gambar, narasumber, benda atau hasil-hasil budaya. Dengan adanya berbagai sumber belajar dapat memberikan pemahaman siswa terhadap materi lebih mendalam dan memahaminya.

Penelitian ini bertujuan untuk mengetahui bagaimana pengelolaan pembelajaran tematik dengan kondisi-kondisi yang telah disebutkan di atas. Meskipun hampir semua guru belum dibekali dengan pelatihan terkait pengelolaan pembelajaran tematik tetapi secara penempatan berada di kelas tematik serta masalah-masalah lain yang muncul dalam pengelolaan pembelajaran tematik.

Dengan adanya penelitian ini juga dapat memberikan sumbangan informasi baik bagi guru, sekolah maupun dinas pendidikan setempat dalam meningkatkan kualitas pengelolaan pembelajaran tematik yang sesuai dengan tuntutan KTSP.

Dalam KTSP untuk tingkat Sekolah Dasar kelas rendah (1, 2 dan 3) pembelajaran dikemas dalam tema-tema. Kunandar (2007, p.333) menyatakan tema merupakan alat atau wadah untuk mengenal- kan berbagai konsep kepada anak didik secara utuh. Pembelajaran tematik merupakan suatu strategi pembelajaran yang melibatkan beberapa mata pelajaran untuk memberikan pengalaman bermakna kepada siswa. Keterpaduan dalam pembelajaran ini dapat dilihat dari aspek proses atau waktu, aspek kurikulum, dan aspek belajar mengajar.

Menurut Rusman (2011, p.253), pembelajaran tematik merupakan salah satu model dalam pembelajaran terpadu (integrated instruction) yang merupakan suatu sistem pembelajaran yang memungkinkan siswa, baik secara individual maupun kelompok. aktif menggali dan menemukan konsep serta prinsip-prinsip keilmuan holistik, bermakna, dan autentik.

Pembelajaran terpadu berorientasi pada praktik pembelajaran yang sesuai dengan kebutuhan dan perkembangan siswa. Ada beberapa prinsip dasar yang perlu diperhatikan, yaitu: 1) bersifat integrasi dengan lingkungan, 2) bentuk belajar dirancang agar siswa menemukan tema, dan 3) efisiensi yaitu memiliki nilai efisiensi antara lain segi waktu, beban materi, metode, penggunaan sumber belajar yang otentik sehingga mencapai ketuntasan kompetensi secara tepat.

Pembelajaran terpadu berorientasi pada praktik pembelajaran yang sesuai dengan kebutuhan dan perkembangan siswa. Ada beberapa prinsip dasar yang perlu diperhatikan, yaitu: 1) bersifat integrasi dengan lingkungan, 2) bentuk belajar dirancang agar siswa menemukan tema, dan 3) efisiensi yaitu memiliki nilai efisiensi antara lain segi waktu, beban materi, metode, penggunaan sumber belajar yang otentik sehingga mencapai ketuntasan kompetensi secara tepat.

Tahapan perkembangan tingkah laku belajar siswa sekolah dasar sangat dipengaruhi oleh aspek-aspek dari dalam dirinya dan lingkungan. Untuk itu, teori yang dikembangkan oleh Piaget begitu berkenaan dengan perkembangan belajar anak pada usia sekolah dasar. Menurut Piaget (setiap anak memiliki cara tersendiri dalam menginterpretasikan dan beradap- 
tasi dengan lingkungannya (teori kognitif). Setiap anak memiliki struktur kognitif yang disebut schemata, yaitu sistem konsep yang ada dalam pikiran sebagai hasil pemahaman terhadap objek yang ada dalam lingkungannya. Pemahaman terhadap objek berlangsung melalui proses asimilasi, yaitu menghubungkan objek dengan konsep yang sudah ada dalam pikirannya dan mengakomodasi dengan proses memanfaatkan konsep-konsep dalam pikirannya untuk menafsirkan objek yang dilihatnya. Suyono\&Hariyanto (2012, p. 144) belajar kognitif adalah belajar dengan tujuan membangun struktur kognitif siswa. Belajar kognitif terkait dengan pemrosesan informasi dalam benak siswa. Informasi yang diproses oleh otak pembelajaran be-rupa pengetahuan yang dapat berupa konsep, prosedur, dan prinsipprinsip.

Kecenderungan belajar anak usia sekolah dasar memiliki tiga ciri, yaitu kongkret, integratif, dan hierarkis. Kongkret mengandung makna proses belajar beranjak dari hal-hal yang kongkret yakni dapat dilihat, didengar, dibaui, diraba, dan diotak-atik, dengan titik penekanan pada pemanfaatan lingkungan sebagai sumber belajar yang dapat dioptimalkan untuk pencapaian proses dan hasil pembelajaran yang berkualitas bagi anak sekolah dasar. Integratif berarti memandang sesuatu yang dipelajari sebagai suatu keutuhan dan terpadu. Sedangkan hierarkis adalah berkembang secara bertahap mulai dari halhal yang sederhana ke hal-hal yang lebih kompleks.

Dari penjelasan terkait pembelajaran tematik pada tingkat sekolah dasar dapat dikatakan bahwa model pembelajaran ini sangat penting bagi siswa yang berada di rentan usia dini yakni kelas 1 sampai 3 . Hal ini dikarenakan cara berpikir siswa pada usia ini terbentuk dalam satu kesatuan sehingga membentuk sebuah konsep pemahaman yang utuh dan berkualitas. Pemisahan pengajaran bagi siswa pada tingkat ini dapat memberikan pengaruh belajar yang tidak menyeluruh dalam proses pembelajaran serta kurang efektif dalam mencapai tujuan pembelajaran. Oleh karena itu, struktur kurikulum pada tingkat SD/MI dikembangkan dalam bentuk pendekatan tematik, dan bentuk pendekatan tematik yang sesuai adalah bentuk tematik dengan organisasi multidisiplin. Disini guru mengembangkan berbagai tema dalam kegiatan pembelajaran yang dapat dikembangkan secara bersamaan dan posisi mata pelajaran tersebut adalah sejajar. Karena struktur kurikulum sudah dikembangkan sedemikian rupa, kurikulum SD/MI level bawah adalah merupakan suatu model kurikulum tematik.

Pengelolaan pembelajaran tematik yang dilakukan guru mulai dari tahap perencanaan, pelaksanaan dan penilaian. Menurut Suryosubroto (2007, p.137) bahwa perencanaan sangat menentukan keberhasilan suatu pembelajaran tematik maka perencanaan yang dibuat dalam rangka pelaksanaan pembelajaran tematik harus sebaik mungkin. Hal senada juga diungkapkan Rusman (2013, p.260) bahwa keberhasilan pelaksanaan pembelajaran tematik dipengaruhi oleh seberapa jauh pembelajaran tersebut direncanakan sesuai dengan kondisi dan potesi siswa.

Untuk itu dalam pengelolaan pembelajaran tematik, guru harus menyiapkan langkah-langkah komprehensif demi berjalannya proses pembelajaran tematik yang ideal dalam memberikan kontribusi positif bagi kemajuan pendidikan baik untuk skala nasional maupun lokal.

\section{Metode Penelitian}

Jenis Penelitian

Jenis penelitian yang digunakan dalam penelitian ini adalah kualitatif yang mengungkapkan fenomena yang terjadi secara apa adanya dan berusaha memaparkan data terkait bagaimana pemahaman pengelola sekolah terhadap penerapan pembelajaran tematik serta faktor-faktor apa saja yang mempengaruhi pembelajaran tematik

\section{Waktu dan Tempat Penelitian}

Tempat penelitian ini dilaksanakan di SD Negeri1, 2, dan 3 Kecamatan Bula, 
Kabupaten Seram Bagian Timur. Penelitian ini dilaksanakan pada bulan Januari hingga Maret 2013 dengan tahapan pengumpulan data berupa wawancara, mengamati dan mencari informasi yang berhubungan dengan fokus permasalahan penelitian terkait dengan penerapan pembelajaran tematik dalam konteks KTSP.

\section{Target/Subjek Penelitian}

Penelitian ini menggunakan teknik purposive sampling dimana sampel yang diambil adalah guru kelas III pada SD Negeri 1, 2, dan 3 Bula, kepala sekolah beserta siswa-siswa yang terlibat langsung dalam proses pembelajaran tematik. Selain itu, subjek penelitian lainnya adalah kepala sekolah sebagai penanggung jawab dalam pengelolaan pembelajaran tematik.

Prosedur

Penelitian ini dilakukan secara langsung dengan mengamati permasalahan yang diteliti tentang bagaimana pengelolaan pembelajaran. Data-data diperoleh dengan cara mewancarai langsung subjek penelitian dengan berbekal panduan wawancara, observasi terkait pelaksanaan pembelajaran tematik dan dokumentasi.

Data, Intrumen, dan Teknik Pengumpulan Data

Data-data yang didapatkan dari hasil wawancara dan observasi dari panduan yang sudah dibuat sebelumnya berupa kisi-kisi instrumen. Teknik pengumpulan data meliputi wawancara, observasi dan dokumentasi.

\section{Teknik Analisis Data}

Dalam penelitian kualitatif, data diperoleh dari berbagai sumber dengan menggunakan teknik pengumpulan data yang sudah ditentukan dan dilakukan terus-menerus sampai datanya jenuh. Analisis data dilakukan dengan mengorganisasikan data, menjabarkannya ke dalam unit-unit, melakukan sintesa, menyusun ke dalam pola, memilih mana yang penting dan akan dipelajari, dan membuat kesimpulan. Analisis data yang diproses tujuan- nya untuk mencari dan menyusun secara sistematis data yang diperoleh dari wawancara, observasi, dokumentasi, catatan lapangan, dan bahan-bahan lain sehingga dapat mudah dipahami dan temuannya dapat diinformasikan kepada orang lain.

\section{Hasil Penelitian dan Pembahasan}

Perencanaan

Perencanaan pembelajaran tematik merupakan tahapan-tahapan yang harus dilakukan oleh seorang guru kelas yang ditempatkan pada kelas tematik. Sebagaimana yang sudah diketahui bahwa dalam menerapkan pembelajaran tematik harus mengikuti prinsip-prinsip dasar yang menjadikan siswa belajar secara kontekstual dan holistik. Dan tugas guru menyajikan pembelajaran yang bermakna dengan mengkaitkan beberapa mata pelajaran dengan basisnya adalah tema.

Perencanaan sangat menentukan keberhasilan suatu pembelajaran tematik, maka guru bertanggung jawab untuk merancang pelaksanaan pembelajaran sebaik mungkin. Dan tentunya proses pembuatan rancangan ini tidak keluar dari standar isi yang sudah ditetapkan dalam KTSP khususnya untuk penerapan pembelajaran pada kelas rendah (1, 2 dan 3) dengan pendekatan tematik. Oleh karena itu, ada beberapa langkah yang perlu dilakukan oleh guru tematik dalam merancang pembelajaran tematik. Berikut digambarkan tahapan-tahapan perencanaan pembelajaran tematik.

Tabel 1. Tahapan Perencanaan Pembelajaran Tematik

\begin{tabular}{|c|l|}
\hline No & \multicolumn{1}{|c|}{ Tahapan Perencanaan } \\
\hline 1 & $\begin{array}{l}\text { Mempelajari kompetensi dasar pada kelas } \\
\text { dan semester yang sama dari setiap mata } \\
\text { pelajaran }\end{array}$ \\
\hline 2 & $\begin{array}{l}\text { Memilih tema yang dapat mempersatukan } \\
\text { kompetensi-kompetensi untuk setiap kelas } \\
\text { dan semester }\end{array}$ \\
\hline 3 & $\begin{array}{l}\text { Membuat "matriks" hubungan } \\
\text { kompetensi dasar }\end{array}$ \\
\hline 4 & Membuat pemetaan pembelajaran tematik \\
\hline 5 & $\begin{array}{l}\text { Menyusun silabus dan rencana } \\
\text { pembelajaran berdasarkan matriks / } \\
\text { jaringan topik pembelajaran tematik }\end{array}$ \\
\hline
\end{tabular}


Pada setiap sekolah dasar di kecamatan Bula yakni SDN 1, 2, dan 3 Bula sudah melakukan perencanaan pembelajaran tematik. Hal ini dilihat pada perangkat pembelajaran tematik setiap guru kelas III. Pada prinsipnya guru-guru tersebut sebelum melaksanakan pembelajaran di awal semester harus memiliki perangkat pembelajaran tematik. Semua terlihat jelas dan nyata bahwa guru kelas III sudah memilikinya meskipun dalam proses ada sebagian guru yang mendapatkan perangkat pembelajaran tematik dengan menyalin dari perangkat yang sudah lengkap melalui teman/rekan yang mengikuti pelatihan.

Pengamatan yang dilakukan pada masing-masing sekolah dasar yaitu SD Negeri 1, 2 dan 3 dalam perencanaan pembelajaran tematik sesuai dengan model pembelajaran tematik dimana guru sudah menyiapkan perangkat pembelajaran berupa silabus dan RPP tematik.

Meskipun demikian dalam proses perencanaan pembelajaran tematik terdapat sekolah yang tidak memiliki pedoman penyusunan model pembelajaran tematik. Hal ini karena, sebagian guru yang meminjam pedoman tersebut tidak mengembalikan kembali ke pihak sekolah sehingga menjadikan sebagian guru yang lain yang akan menyusun perangkat pembelajaran merasa kesulitan untuk membuatnya. Oleh karena itu, salah satu cara guru memiliki perangkat pembelajaran yaitu mengusahakan dengan menyalin perangkat yang sudah lengkap dari teman yang mengikuti pelatihan KTSP bahkan sudah dicetak dengan rapi. Guru bersangkutan hanya siap membayar dan mengambil perangkat tersebut secara lengkap. Mengenai perencanaan di salah satu SD guru tersebut mengusahakan dengan cara demikian.

Pada SD Negeri 1 dan 2 Bula memiliki pedoman penyusunan model pembelajaran tematik berupa perangkat pembelajaran (silabus dan RPP). Tetapi prosesnya tidak jauh berbeda dengan kondisi yang terjadi pada SD Negeri 3. SD Negeri 2 meskipun memiliki pedoman tetapi tetap juga mengadaptasi dari perangkat pembelajaran yang sudah lengkap. Apapun fenomena yang terjadi bahwa terkait dengan perencanaan pembelajaran tematik guru sudah memiliki persiapan perangkat pembelajaran meskipun proses yang dilakukan praktis dan mudah.

Semua tahapan perencanaan pembelajaran tematik dilakukan dengan tepat karena terlihat dari perangkat pembelajaran yang dimiliki oleh masing-masing guru pada setiap sekolah SD Negeri 1, 2, dan 3 Bula. Meskipun pada hakikatnya perangkat pembelajaran tersebut didapatkan dengan cara copy file dari perangkat pembelajaran yang sudah ada sebelumnya. Dan hal menunjukkan tingkat usaha guru untuk memiliki administrasi pembelajaran yang lengkap dan persiapan yang baik sebelum memulai pembelajaran.

\section{Pelaksanaan}

Pada tahapan ini merupakan inti dalam melaksanakan rencana pembelajaran yang telah disusun sebelumnya. Pembelajaran tematik ini akan diterapkan dengan baik apabila didukung dengan pemahaman guru yang memahami model pembelajaran tematik dan tersedianya sarana belajar yang memadai.

Pelaksanaan pembelajaran tematik pada sekolah SD Negeri 1, 2, dan 3 sesungguhnya menunjukkan ketidaksesuaian dari skenario yang dibuat sebelumnya. Seperti yang diketahui bahwa perangkat pembelajaran berupa silabus dan RPP dibuat secara tematik yakni menggabungkan beberapa mata pelajaran yang seharusnya disampaikan secara terpadu agar membentuk pemahaman siswa secara utuh dan bermakna, tetapi realisasinya terlihat kontras. Kondisi yang terjadi adalah pembelajaran dilakukan secara terpisah/permata pelajaran sehingga menunjukkan ketidaksesuaian dari rencana pembelajaran yang sudah dibuat sebelumnya. Alasan pembuatan rencana pembelajaran tersebut hanya untuk kelengkapan administrasi yang harus diperiksa oleh kepala sekolah serta sebagai kelengkapan dokumen II sekolah yang setiap waktu tertentu 
akan diperiksa oleh pengawas tingkat kecamatan/kabupaten.

Pelaksanaan pembelajaran tematik secara terpisah juga diakibatkan karena pemahaman guru terhadap pengelolaan pembelajaran tematik belum didapatkan terutama diikutkan dalam pelatihan model pembelajaran tematik. Sehingga konsep pemahaman ini dirasa sama dengan pelaksanaan model pembelajaran lainnya. Intinya materi pada setiap mata pelajaran tersampaikan kepada siswa. Bahkan ada juga guru yang beranggapan bahwa tematik itu yang terpenting siswa dapat membaca, menulis dan menghitung. Seperti itulah pemahaman yang dipahami sebagian guru terkait dengan pembelajaran tematik.

Penerapan pembelajaran tematik pada sekolah SD Negeri 2 dan 3 Bula. Dalam tahap perencanaan, masing-masing guru kelas III pada sekolah tersebut sudah menyiapkan perangkat pembelajaran tematik. Akan tetapi ternyata kondisi yang terjadi pada kedua sekolah tersebut adalah sama yakni menerapkan model pembelajaran dengan pendekatan per mata pelajaran/bukan tematik. Pelaksanaan pembelajaran tematik terlihat kontras dari perencanaan pembelajaran yang sudah dibuat. Ketika ditanyakan kepada salah satu guru yang ada di sekolah SD Negeri 3 Bula terkait bagaimana penerapan tematik yang dilakukan, jawabannya adalah bahwa sesungguhnya penerapan tematik yang dilakukan pada kelas III tidak dengan penerapan tematik melainkan mata pelajaran. Hal ini karena guru yang ditempatkan pada kelas tematik belum memahami bagaimana konsep tematik yang sebenarnya ditambah lagi belum mengikuti pelatihan terkait model pembelajaran tematik sehingga penerapan yang dilakukan adalah dengan pendekatan per mata pelajaran.

Pelaksanaan model pembelajaran seperti ini juga menunjukkan tingkat pengawasan kepala sekolah maupun pengawas sekolah setempat belum menyeluruh termasuk aspek pelaksanaan pembelajaran yang dilakukan oleh guru.Pengawasan kepala sekolah tetap ada meskipun hanya sampai pada kelengkapan adminitrasi perangkat pembelajaran yang dibuat tetapi tidak pada praktiknya. Dan pengawasan lain berupa perkembangan belajar siswa dalam hal apakah siswa sudah dapat membaca, menulis, dan menghitung (calistung). Hal ini disebabkan sebagian siswa masih ada yang perkembangan baca, tulis dan hitung masih perlu pengayaan dan perhatian khusus dari sekolah. Dengan demikian penerapan pembelajaran lebih diutamakan untuk program belajar calistung (membaca, menulis, dan menghitung).

Sedangkan pada sekolah SD Negeri 2 Bula juga menerapkan model pembelajaran dengan pendekatan mata pelajaran/bukan tematik meskipun perencanaan pembelajaran yang dibuat secara tematik. Guru bersangkutan belum memahami seperti apa penerapan pembelajaran tematik, ketika ditanyakan pembelajaran yang diterapkan pada kelas III apakah dengan pendekatan tematik. Tanggapannya bahwa penerapan pembelajaran yang dilakukan secara terpisah atau tidak menggabungkan menjadi satu tema. Hal ini karena belum memahami model pembelajaran tematik ditambah sosialisasi terkait belum pernah didapatkan apalagi diikutkan dalam pelatihan pembelajaran tematik. Selain itu, guru-guru yang ada pada kelas rendah juga penerapannya dengan pendekatan mata pelajaran sehingga guru bersangkutan menyimpulkan sendiri bahwa penerapan untuk kelas III sama saja dengan kelas dibawahnya yakni kelas I dan II.

Pengamatan yang dilakukan pada sekolah SD Negeri 1 Bula boleh dikatakan cukup sesuai dengan apa yang dituntutkan dalam Kurikulum Tingkat Satuan Pendidikan (KTSP) dari segi perencanaan meskipun demikian dalam proses pelaksanaannya masih kurang baik. Dalam menerapkan pembelajaran tematik yang ideal adalah aspek keterlibatan siswa belajar secara aktif dalam menemukan konsep-konsep pembelajaran. Siswa lebih aktif dan guru menyajikan pembelajaran secara utuh dan bermakna sehingga konsep-konsep tersebut dengan mudah dipahami oleh siswa. Pembelajaran didesain 
dengan lebih kreatif dan inovatif, siswa mempelajari materi-materi secara kontekstual dan mengalami secara langsung kegiatan belajar.Hal ini belum ditemukan pada sekolah SD Negeri 1 Bula terutama pada kelas III.

Guru melakukan pembelajaran lebih pada tranformasi pengetahuan dari setiap materi yang ada, siswa cenderung mengikuti apa yang disampaikan dan guru lebih banyak menggunakan metode ceramah/ kurang variasi metode. Padahal dengan berbagai metode yang digunakan guru dapat menumbuhkan motivasi siswa dalam kegiatan belajar, menumbuhkan interest siswa terhadap kegiatan belajar. Tetapi yang terjadi proses KBM lebih menunjukkan guru sebagai single actor yang mengatur semuanya. Oleh karena itu, pembelajaran yang diterapkan lebih bersifat monoton atau penguasaan sepenuhnya ada di tangan guru. Padahal pembelajaran tematik menuntun adanya kerja sama antara guru dan siswa, siswa dan siswa sehingga menjadikan suasana pembelajaran yang aktif, inovatif, kreatif, efektif dan menyenangkan (PAKEM). Alasan ini karena guru menilai bahwa penyerapan siswa yang rendah atas materi-materi yang disampaikan. Hal yang terjadi juga siswa masih kurang dalam memperhatikan pembelajaran yang sedang berlangsung.

Dengan penerapan seperti yang sudah dikemukakan di atas bahwa pada sekolah SD Negeri 2 dan 3 Bula belum menerapkan model pembelajaran tematik sebagaiman yang diatur dalam peraturan menteri No 22 Tahun 2006. Hal ini menjadi sebuah perhatian penting bagi kepala sekolah dan pengawas yang ketika secara administratif dapat memeriksa perangkat pembelajaran tematik secara lengkap, maka secara praktik yang dilakukan di dalam kelas juga harus memperhatikan model pembelajaran yang sedang dilakukan. Jika perlu, harus diadakan micro teaching bagi guru yang akan ditempatkan pada kelas tematik. Tetapi realisasi pengawasan dalam bentuk praktek penerapan pembelajaran belum terlaksana dengan baik dan guru sangat kurang dibekali dengan pemahaman yang utuh terkait penerapan pembelajaran tematik. Model pembelajaran yang dilaksanakan sesuai dengan jadwal mata pelajaran yang sudah ditentukan meskipun penyebutan kelasnya adalah kelas tematik. Penerapan pembelajaran yang secara terpisah menjadikan guru sulit dalam mengembangkan suatu pembaharuan dalam kegiatan pembelajaran. Keadaan ini disebabkan guru harus menguasai semua mata pelajaran dan mengajarkannya sehingga terasa begitu beban dalam mengaplikasikannya. Masalah lain yang didapati juga adalah saling tumpang tindihnya proses kegiatan belajar. Karena guru terbatas waktu dalam menyampaikan materi. Ketika satu materi sedang diajarkan sementara misalnya sudah waktu pergantian jam, maka materi yang sebelumnya tersebut dihentikan kemudian dilanjutkan dengan materi lain dengan mata pelajaran yang berbeda.

Penerapan pembelajaran tematik juga didukung oleh sarana belajar lainnya berupa laboraturium atau media belajar yang membantu memudahkan guru dan siswa belajar secara aktif dengan media-media yang tersedia dan sumber belajar tidak sebatas buku teks, tetapi dapat diusahakan sendiri dan berkenaan dengan kebutuhan belajar.Pada pengamatan yang dilakukan bahwa terkait sarana belajar yang difasilitasi sekolah tentu ada, tetapi dari segi pemanfaatan belum terealisasi. Misalnya pada SD Negeri 2 Bula, ketika ditanyakan bagaimana dengan sarana belajar yang tersedia. Sekolah masih kurang memfasilitasi pembelajaran yang didukung oleh media belajar. Hal ini karena, kondisi sekolah dalam masa peralihan kepemimpinan yang baru sehingga harus ada pertanggung jawaban sebelumnya dan setelah itu dapat menggunakannya.

Sarana belajar yang memadai menjadi faktor penting dalam pelaksanaan pembelajaran. Semua komponen dalam proses pembelajaran saling mendukung. Pemahaman guru yang kurang dalam menerapkan konsep tematik dengan baik menjadi masalah untuk merealisasikan penerapan tematik sesungguhnya. Faktor 
guru menjadi ujung tombak untuk mensukseskan penerapan kurikulum dan didukung dengan sarana belajar yang ideal. Pihak sekolah maupun instansi terkait bertanggung jawab dalam penerapan ini. Dengan pemahaman/kemampuan guru yang baik, pengawasan yang baik, fasilitas belajar yang mendukung, lingkungan yang kondusif dapat memberikan kualitas pendidikan yang bermutu dan mampu bersaing. Tidak hanya untuk daerah, tetapi kualitas pendidikan secara nasional.

Kondisi yang sama juga terjadi pada SD Negeri 3 Bula, bahwa pada kelas III belum terfasilitasi media pembelajaran dalam proses pelaksanaan pembelajaran. Dan dalam pembelajaran yang terlihat guru hanya menggunakan sumber belajar berupa buku teks dan LKS

Penilaian

Model penilaian yang dikembangkan dalam pembelajaran tematik di Sekolah Dasar mencakup prosedur yang digunakan, jenis dan bentuk penilaian, serta alat evaluasi yang digunakan. Pada dasarnya model penilaian tematik disesuaikan dengan penilaian berbasis kelas pada Kurikulum Tingkat Satuan Pendidikan (KTSP).

Penilaian yang dilakukan pada masing-masing sekolah yakni SD Negeri 1 , 2, dan Bula memiliki ciri khas yang hampir sama.Kegiatan penilaian dilakukan dengan menggunakan instrumen penilaian berupa ulangan harian ke1 s/d 3, ujian tengah semester (UTS) dan ujian akhir semester (UAS).

Pada sekolah SD Negeri 1 yang memang menerapkan pembelajaran tematik melaksanakan penilaian/evaluasi pembelajaran secara terpisah dengan mengacu pada SK/KD dan indikator yang sudah selesai diajarkan kepada siswa. Penilaian proses dilakukan ketika siswa terlibat dalam pembelajaran, apakah siswa serius mengikuti pembelajaran atau melakukan aktifitas lain dan guru memiliki catatancatatan tersebut untuk mengevaluasi tingkat keaktifan siswa. Penilaian proses juga seperti menanyakan kembali materi yang sudah diajarkan atau dengan menindaklanjuti berupa pemberian tugas/ latihan baik yang dikerjakan di dalam kelas maupun dirumah (PR). Bahkan hampir semua siswa memiliki lembar kerja siswa (LKS) untuk memudahkan tugas/latihan yang diberikan guru.Semua komponen tersebut sudah dibuat dalam rancangan penilaian tematik.

Selain itu, penilaian juga dilakukan dengan diadakan evaluasi formal dimana sekolah bertanggung jawab untuk menetapkan jadwal berupa ulangan harian yang diadakan sampai tiga kali, ujian tengah semester dan ujian akhir semester dimana pada ujian akhir semester merupakan akhir proses pembelajaran dalam satu semester. Penilaian hasil belajar berupa ulangan harian $(1,2$, dan 3$)$, ujian tengah semester dan ujian akhir semester sebagai sebuah proses pemberian nilai terhadap hasil-hasil belajar yang dicapai dengan menggunakan kriteria tertentu. Kriteria ini menjadi sebuah kebijakan yang sudah ditetapkan oleh pihak sekolah dan ditindaklanjuti oleh guru tersebut dalam menentukan kriteria ketuntasan siswa dalam melaksanakan proses pembelajaran. Jika ada siswa yang tidak tuntas, maka diadakan remedial bagi siswa yang tidak mencukupi standar kriteria kelulusan minimal (KKM).

Pada sekolah SD Negeri 2 dan 3 Bula juga melaksanakan penilaian proses dan hasil pembelajaran, meskipun penerapan pembelajaran pada kelas III bukan pembelajaran tematik. Penilaian dikembalikan pada setiap mata pelajaran dengan melihat ketuntasan siswa dalam KBM.Setiap selesai pembelajaran/KBM siswa biasanya diberikan tugas/latihan terkait pembelajaran yang sudah dilakukan. Siswa memiliki sumber belajar lainnya seperti LKS (lembar kerja siswa) untuk memudahkan tugas/ latihan yang diberikan guru.

Masing-masing sekolah hampir sama memiliki format penilaian yang mencakup semua bentuk penilaian hasil pembelajaran dan semua itu digambarkan dalam bentuk angka-angka/huruf. Dari semua rangkaian 
pembelajaran yang dilakukan dalam satu semester, tugas guru dan sekolah melaksanakan evaluasi akhir berupa ujian akhir semester dan hasil penilaian tersebut kemudian dituangkan dalam bentuk pelaporan yang dibuat sebagai sebuah pertanggung jawaban sekolah pada orang tua/wali siswa, komite sekolah, masyarakat dan instansi terkait. Laporan ini merupakan sarana belajar siswa, komunikasi dan sarana kerja sama antar sekolah dan orang tua bagi kemajuan belajar siswa maupun pengembangan sekolah. Bentuk pelaporan pembelajaran tematik pada dasarnya masih sama dengan yang sudah ada saat ini karena penilaian pembelajaran tematik dilakukan secara terpisah sesuai dengan kompetensi pada masing-masing mata pelajaran.

Faktor-faktor yang mempengaruhi.

Dalam melaksanakan pembelajaran tematik pada Sekolah Dasar yakni SD Negeri 1, 2 dan Bula menemukan kendalakendala atau faktor yang mempengaruhi terselenggaranya pembelajaran tematik, diantaranya faktor-faktor tersebut sebagai berikut:

a. Belum terlaksananya KKG (kelompok kerja guru) pada setiap sekolah dasar termasuk SD Negeri 1, 2 dan 3 Bula. Hal ini menjadikan guru terbatas dalam mendapatkan informasi penting terkait model pembelajaran yang diterapkan. Guru tidak memiliki sarana komunikasi dalam bentuk komunitas yang menambah pengetahuan dan ketrampilan dalam meningkatkan kualitas pembelajaran. KKG menjadi sebuah solusi untuk memberikan sumbangan pemikiran maupun pengetahuan baru terkait penerapan pembelajaran tematik. Tetapi itu hanya sebuah harapan yang tidak ada realisasi dari kebijakan pemerintah pada semester genap.

b. Penempatan guru kelas tematik tidak disertai dengan pemahaman yang baik terkait bagaimana menerapkan pembelajaran tematik. Sehingga guru yang harusnya menerapkan model pembel- ajaran tematik tetapi tidak menerapkannya sesuai dengan tuntutan KTSP. Gambaran keadaan ini terjadi pada sekolah SD Negeri 2 dan 3 Bula. Penerapan pembelajaran dengan memisahmisahkan antar mata pelajaran. Ketika ditanyakan karena belum memahami dan merasa sulit untuk menerapkannya ditambah lagi penerapan pada kelas di bawah juga secara terpisah.

c. Pada kelas III di setiap sekolah dasar menampung jumlah siswa yang cukup banyak ditambah beban mengajar yang banyak. Dimana guru SD Negeri 2 dan SD Negeri 3 harus mengajarkan semua mata pelajaran. Hal ini memungkinkan guru sangat terbatas mengembangkan kreatifitas pembelajaran. Pembelajaran terasa begitu membebankan karena satu guru mengajarkan semua mata pelajaran ditambah harus mengurusi jumlah siswa rata-rata di atas 30 bahkan sampai 40 lebih siswa. Jumlah siswa terbanyak terdapat pada SD Negeri 3 Bula dengan total 42 siswa untuk tingkatan kelas III saja.

d. Dengan jumlah siswa yang banyak, guru merasa sulit melakukan pengelolaan pembelajaran. Terkadang ketika pembelajaran sudah mulai siswa masih juga melakukan aktifitas lain sehingga terkadang guru harus mengamankan siswa kembali untuk memulai kegiatan belajar mengajar. Meskipun jumlah siswa pada SD Negeri 1 dan 2 Bula berkisar 30 lebih tetapi guru masih merasa sulit dalam mengelola kelas dengan jumlah siswa yang banyak. Guru berharap ada guru bantu atau tambahan agar memudahkan KBM dan administrasi kelas.

e. Orang tua masih kurang dalam memperhatikan dan mengawasi jam belajar anak di rumah sehingga tanggung jawab pendidikan lebih banyak di pundak guru di sekolah. Bahkan terkadang guru harus mendatangi rumah siswa ketika ada siswa yang bermasalah dalam perkembangan belajar di sekolah. 


\section{Simpulan}

Secara rinci penerapan pembelajaran tematik pada beberapa sekolah dasar negeri tersebut adalah sebagai berikut:

1. Pada tahap perencanaan pembelajaran tematik, guru menyiapkan perangkat pembelajaran meskipun dengan cara copy file dari perangkat yang sudah jadi.

2. Pelaksanaan pembelajaran tematik terlihat kontras/tidak sesuai dengan perencanaan pembelajaran yang sudah dibuat sebelumnya dan kurang variasi metode pembelajaran.

3. Evaluasi/penilaian proses dan hasil pembelajaran tematik pada masingmasing sekolah sama yakni meliputi UH 1 s/d 3, UTS, dan UAS serta tugastugas yang dikerjakan siswa baik di kelas maupun PR (pekerjaan rumah).

4. Faktor-faktor yang mempengaruhi pelaksanaan pembelajaran adalah belum terlaksananya KKG sehingga guru tidak memiliki ruang diskusi untuk meningkatkan pembelajaran serta belum memahami dengan baik penerapan pembelajaran tematik, jumlah siswa yang terlalu banyak, sarana pembelajaran yang masih minim dan sikap orang tua yang masih kurang memperhatikan waktu belajar anak di rumah.

Saran

Pengelolaan pembelajaran tematik memperhatikan hal-hal yang mendukung terselenggaranya pengajaran tematik yang baik. Salah satunya berupa memberikan pemahaman dalam mengelola proses pembelajaran tematik yang ideal. Tidak hanya sekedar membuat perangkat pembelajaran secara tematik, tetapi dalam pelaksanaanya juga harus secara tematik. Karena konsep yang akan dibangun kepada siswa adalah memberikan kebermaknaan terhadap proses pembelajaran bukan sekedar menuntaskan penyampaian materi.

\section{Daftar Pustaka}

Abdul Majid. (2012). Perencanaan pembelajaran. Bandung: PT Remaja Rosdakarya.
Andi Prastowo. (2012). Panduan kreatif membuat bahan ajar inovatif. Yogyakarta: Diva Press

Anggani Sudono. (2010). Sumber belajar dan alat permainan; untuk pendidikan usia dini. Jakarta: PT Grasindo.

Baharuddin dan Esa Nur Wahyuni. (20100. Teori belajar dan pembelajaran. Yogyakarta: Ar-Ruzz Media.

Byrnes, P. James. (2008). Cognitive development and learning; In instructional contexts. Boston: Pearson Education, Inc.

Depdikdas. (2006). Panduan penyusunan kurikulum KTSP jenjang pendidikan dasar dan menengah. Jakarta: BSNP.

Djemari Mardapi. (Oktober 2004). Kurikulum dan evaluasi. Makalah disajikan dalam Konapsi V, di Universitas Negeri Surabaya.

Eko Putro Widoyoko. (2010). Evaluasi program pembelajaran. Yogyakarta: Pustaka Pelajar.

Glanz, J. (2009). Teaching 101; classroom strategies for beginning teacher. California: Corwin.

Hamid Hasan. (2009). Evaluasi kurikulum. Bandung: PT Remaja Rosdakarya.

Http//: www.serambagiantimurkab.go.id. Pemkab SBT Targetkan 2009, Kendala Utama Pengahambat Peningkatan Mutu Pendidikan di SBT selesai. Diambil pada tanggal 1 Januari 2013.

Jamal Ma'mur Asmani (2012). Tujuh tips aplikasi PAKEM. Yogjakarta: Diva Press

Jamil Suprihatiningrum. (2013). Strategi pembelajaran; teori dan praktek. Yogyakarta. Ar-Ruzz Media.

Jejen Musfah. (2011). Peningkatan kompetensi guru; melalui pelatihan dan sumber belajar teori dan praktik. Jakarta: Kencana Prenada Media Group.

Killen, R. (2009). Effective teaching strategies. Sydney. National Library of Australia Cataloguing-in-Publication Data. 
Kunandar. (2007). Guru profesional; implementasi kurikulum tingkat satuan pendidikan (KTSP) dan sukses dalam sertifikasi guru. Jakarta: PT Rajagrafindo Persada.

Parise. L. M \& James P. Spilane. The elementary chool journal. journal. Vol. 110, No. 3, March 2010. Chicago: The University Of Chicago.

Marsh, C. (1996). Handbook for beginning teachers. South Melbourne: Wesley Longman Australia Pty Limited.

McGill, I dan Anne Brockband (2004). The action learning handbook. Great Britain: Routledge Falmer.

Muhammad Joko Susilo. (2008). Kurikulum tingkat satuan pendidikan. Yogyakarta: Pustaka Pelajar.

Mulyasa. (2007). Kurikulum tingkat satuan pendidikan; suatu panduan praktis. Bandung PT RemajaRosdakarya.

Nana Syaodih Sukmadinata. (2011). Pengembangan purikulum; teori dan praktik. Bandung: PT Remaja Rosdakarya.

Nana Sudjana. (2011). Dasar-dasar proses belajar mengajar. Bandung: Sinar Baru Algensindo.

Oemar Hamalik. (2010). Manajemen pengembangan kurikulum. Bandung: PT Remaja Rosdakarya.
Pupuh Fathurrohman dan Sorby Sutikno. (2011). Strategi belajar mengajar; melalui penanaman konsep umum dan konsep islami. Bandung: PT Refika Aditama.

Rusman. (2011). Manajemen kurikulum. Jakarta: PT Rajagrafindo Persada.

Sardiman.(2011). Interaksi dan motivasi belajar mengajar. Jakarta: Rajawali Press.

Stoll, L, Dean Fink \& Lorna Earl. (2003). It's about learning (it's about time). London: Rouledge Falmer.

Sugiyono. (2010). Metode penelitian kuantitatif, kualitatif, dan RED. Bandung: Alfabeta.

Suryobroto. (2009). Proses belajar mengajar di sekolah. Jakarta: RinekaCipta.

Suyono dan Hariyanto. (2012). belajar dan pembelajaran. Bandung: PT Remaja Rosdakarya.

Trianto. (2007). Model pembelajaran terpadu dalam teori dan praktek. Jakarta: Prestasi Pustaka Publisher.

Udin Syaefudin Saud. (2010). Pengembangan profesi guru. Bandung: Alfabeta.

Utami Munandar. (2009). Pengembangan kreatifitas anak berbakat. Jakarta: Rineka Cipta.

Wina Sanjaya. (2008). Kurikulum dan pembelajaran. Jakarta: Kencana Prenada Media Group. 